\title{
sciendo
}

DOI: 10.2478/orga-2021-0018

\section{The FunCaps Framework: Reconceptualizing Operational Alignment}

\author{
Olfat GANJI BIDMESHK ${ }^{1,2}$, Mohammad MEHRAEEN ${ }^{1,3^{*}}$, \\ Alireza POOYA ${ }^{1}$, Yaghoob MAHARATI ${ }^{1}$
} ${ }^{1}$ Department of Management, Ferdowsi University of Mashhad, Mashhad, Iran, olfat.ganjibidmeshk@mail.um.ac.ir,
m-lagzian@um.ac.ir (*corresponding author), alirezapooya@um.ac.ir, maharati@um.ac.ir

${ }^{2}$ Department of Management Information Systems, Sauder School of Business, University of British Columbia, Vancouver, Canada

${ }^{3}$ Department of Information Systems, DeGroote School of Business, McMaster University, Hamilton, Canada

Background and purpose: Operational alignment, the alignment between business processes (BPs) and information systems (ISs), is a well-acknowledged requirement for improving business efficiency. However, a lack of sound foundation for the practical implementation of operational alignment remains in the existing literature. This is, in part, because previously developed coarse-grained strategic alignment models for operational alignment have overlooked the differences between strategic and operational levels of alignment. Additionally, while some studies have recognized these differences, they remain limited. This is partly due to their negligence of the IS's socio-technical nature or their focus on identifying the social antecedents and their effect on operational alignment, without considering how ISs meet the business requirements in achieving operational alignment. To overcome this potential lack of applicability, the purpose of this paper is to determine the right level of abstraction for describing BPs and ISs and reconceptualizing operational alignment.

Methodology: This paper conducts empirical research using a grounded theory (GT), centering on semi-structured interviews with 28 experts involved in the Iranian top public universities. Data were analyzed by using MAXQDA software.

Results: The resulting FunCaps framework specifies the required combinations of BP functions and IS capabilities for operational alignment.

Conclusion: FunCaps reconceptualizes operational alignment based on operational planning and reciprocal integration and establishes the broader picture by considering an IS as a socio-technical system.

Keywords: Operational alignment, information system, business process, socio-technical system, grounded theory

\section{Introduction}

In the study of information system (IS), it is essential to move from silo to system thinking to achieve ISs and business alignment and improve business efficiency. The IS was considered a separate department of a business, before the 1970s, that did not share the same priorities, goals, or tools with the other departments (Luftman et al. 2017). As a result, the IS department operated as an in- dividual business entity and was viewed solely as a cost for the business (Kappelman et al. 2019). As long as the functions of IS were only maintenance and processing of the records and documents, the silo thinking did not lead to major challenges (Karpovsky and Galliers 2015). However, challenges emerge when competition increases, and as such, efficiency becomes vital for the business. Businesses must move from silo thinking to systems thinking (Bagheri et al. 2019) to improve business efficiency. Systems thinking is a holistic approach focused on how the departments

Received: 28th May 2021; revised: 23rd August 2021; accepted: 20th September 2021 
in a business and their constituents work together efficiently over time. As a result, system thinking necessitates the alignment of business and ISs, as the business constituents, at both strategic and operational levels (Hinkelmann et al. 2016).

To achieve business-IS alignment, we need to realize alignment at both strategic and operational levels. Strategic alignment refers to aligning IS strategies with business strategies and helps meet future IS needs of the business (Levstek et al. 2018). Operational alignment investigates the alignment of ISs with the business by ensuring the effectiveness and efficiency of ISs in supporting daily business operations (Zhou et al. 2018). Additionally, while strategic alignment focuses on "What should be done?" (Henderson and Venkatraman 1993), operational alignment is rooted in answering "How to perform activities?" (Gerow et al. 2016). As such, alignment is not achieved unless it is realized at both strategic and operational levels (Renaud et al. 2016).

Business-IS alignment, at both levels (strategic and operational), has been a main concern of the information technology (IT) leaders since 1984 (Kappelman et al. 2018). Similarly, CIOs at top public universities (TPUs) in Iran remain concerned about the alignment of IS and business process (BP) (hereafter operational alignment). TPUs are leading universities in developing IT/IS capabilities. Despite CIOs' desire for the practical implementation of the existing models and frameworks at TPUs, they are limited in efficient and effective achievement of operational alignment. Therefore, operational alignment remains an open problem for the CIOs at the TPUs.

The concern in achieving operational alignment relates to (1) adaptation of the approaches in strategic alignment for operational alignment and (2) limitations of existing approaches specific for achieving operational alignment. Firstly, while the strategic level is coarse-grained, the operational level is fine-grained. Therefore, in the adaptation of alignment approaches at the strategic level, high-level strategic concepts must be converted into precise, well-defined, and low-level operational concepts. Secondly, although only a handful of the extensive previous studies on business-IS alignment have considered the differences between strategic and operational levels of alignment (Malshe et al. 2017), they remain limited in their applicability to operational alignment. The existing approaches that have used modeling languages (MLs) to link models in BPs and software systems (SSs) (e.g., Aversano et al. 2016; Li et al. 2015; Kraiem et al. 2014) should be improved for achieving operational alignment. Because these studies do not consider SS as a socio-technical system, and yet IS, not considered by MLs, is a sociotechnical system. The remainder of the handful of approaches that have considered the differences between strategic and operational alignment are limited because they do not consider how ISs meet business requirements in achieving operational alignment. Instead, they are focused on identifying social antecedents (e.g., communication) and their effect on the operational alignment (e.g., Wagner et al. 2014; Zhou et al. 2018; Bagheri et al. 2019). The right abstraction level must be used to identify what to include and what to exclude in achieving operational alignment in order to address the limitations of the existing approaches. Abstraction is the process in which some features are chosen to be presented while some are rejected (Kaul et al. 2017). The right level of abstraction, here, means that abstraction must (1) consider the differences between the strategic and operational levels of alignment and translate high-level strategic concepts into low-level operational concepts, (2) consider IS as a socio-technical system, and (3) consider how ISs meet business requirements.

The issues mentioned above necessitate further research to determine:

Research Question: What is the right level of abstraction to describe BPs and ISs for achieving operational alignment?

Here, we used Grounded theory (GT) as a bottom-up approach to scrutinize operational alignment. GT starts from fine-grained elements and classifies them to form coarse-grained dimensions. As a result, using GT, we will achieve a higher-level abstraction without missing lower-level details and elicit the socio-technical aspect of operational alignment.

This paper is organized as follows: Section 2 describes the approaches used in the previous research on business-IS alignment and the research gap. Section 3 explains the use of GT as a research method. Section 4 presents the results of the analysis and coding of the data. Section 5 positions the results of this research in the relevant literature and integrates the results with related model. And, Section 6 discusses the limitations of the study and presents some suggestions for future studies.

\section{Literature review}

Business-IS alignment is an extensively studied topic (Zhou et al. 2018). This section reviews the approaches in the previous literature on business-IS alignment and their research gap.

\subsection{Approaches used in the previous research on business-IS alignment}

The approaches used in the existing studies are categorized into two main categories: (1) approaches that aim to achieve strategic alignment and (2) approaches that aim to achieve operational alignment. We explained selected studies on two main categories in Appendix A. 


\subsection{Research gap}

\subsubsection{Approaches at the strategic level}

Challenges in existing approaches at the strategic level of alignment are rooted in the level of planning and the direction of integration (Grover and Lyytinen 2015). Existing literature at the strategic level is based on strategic planning, while the realization of operational alignment is contingent upon operational planning (Malshe et al. 2017). Strategic planning aims to answer the questions: "Where does the organization want to be in the future?" and "How will organizational vision, mission, and objectives be reached?". In contrast, operational planning supports strategic planning to meet organizational goals (Schwarz et al. 2010). In terms of the direction of integration, the direction of integration in strategic alignment is sequential or reciprocal, while the direction of integration in operational alignment is reciprocal (Rahimi et al. 2016). Sequential integration is one-way planning of business; in other words, IS focuses primarily on providing business support. Reciprocal integration refers to two-way planning with a reciprocal and interdependent relationship between business and IS, where IS plays a role in supporting and influencing business (Teo and King 1997). To achieve operational alignment, we must consider the (1) distinctions between the two levels of planning (strategic and operational) and (2) reciprocal integration.

Our detailed literature review on business-IS alignment at the strategic level showed that proposed models and frameworks are influenced by the strategic level of planning and place a low priority on the reciprocal integration between BPs and ISs. Concerning strategic planning, these models demonstrate the required actions to achieve strategic alignment. These actions are based on long-term objectives dependent on fluctuating environmental conditions and various internal organizational factors (Bergeron et al. 2004). Therefore, models and frameworks at the strategic level are high-level concepts, and not generalizable to operational alignment, based on operational planning and short-term objectives. In terms of reciprocal integration, the models and frameworks for strategic alignment place a low priority on the interplay between BPs and ISs, which is a higher priority for achieving alignment at the operational level (Renaud et al. 2016). According to Pantazi and Georgopoulos (2006), operational alignment is based on a two-way relationship and reciprocal integration, which means that ISs not only facilitate and support the successful implementation of BPs but also increase the agility and flexibility of BPs in conformity with the environmental dynamic. In summary, both the development of ISs based on BPs and the fulfilment of BPs according to ISs, play a crucial role in operational alignment (Trang et al. 2021). However, most of the existing models and frameworks do not take the differences between strategic and operational planning, and the reciprocal integration between BPs and ISs, into account and, therefore, there remains a need for further investigation to realize operational alignment (Kotusev, 2020).

\subsubsection{Approaches at the operational level}

Existing literature at the operational level used one of two approaches: (1) using MLs to link models in BPs and SSs, and (2) focusing on identifying social antecedents and their effect on operational alignment. Studies using MLs to link models in BPs and SSs (e.g., Aversano et al. 2016; Li et al. 2015; Kraiem et al. 2014; Frankova et al. 2011) are commonly based on two fundamentally limiting premises: their focus is limited to SS, and they mainly draw from Strategic Alignment Model (SAM).

The limited focus of previous studies of operational alignment implementation on SS gives rise to challenges for implementing their outcomes. The majority of existing ML approaches have taken up operational alignment by linking models in BP with SS instead of with ISs. Bostrom and Heinen (1977) argue that an IS consists of two interactive parts, namely, technical and social subsystems, where the technical subsystem includes technology, artifacts, processes, tasks, procedures, and physical environment, and the social subsystem comprises elements such as structure and people (with their viewpoints, behaviours, and relationships) (Bostrom and Heinen 1977). According to the socio-technical system (STS) theory, although technical and social subsystems are closely interrelated, they are intrinsically distinct. Technical subsystems aim to attain specified performance parameters. Social subsystems, however, are dependent on humans with unpredictable behaviours. Technical subsystems traditionally dominate the investigation of systems and focus on the technical aspect of SSs without considering the social aspects. Yet, in contrast to SS, IS is a socio-technical system (Walker et al. 2008). Thus, the emerging approaches using MLs should consider IS as a socio-technical system to improve their applicability in achieving operational alignment.

Besides, most ML approaches build on SAM. According to Renaud et al. (2016), SAM is grounded in assumptions that are recognized as no longer valid and hence must be updated by reconceptualizing its dimensions. Others have challenged Henderson and Venkatraman's (1993) valuable model (i.e., SAM) due to its three possible major shortcomings depending on (1) the true nature of organizational strategy, (2) the performativity of the model, and (3) managerial rationality and redundancy of organizational members (Renaud et al. 2016). The first challenge is that SAM takes a managerial and top-down approach in which IS strategy or business strategy is intended exclusively for an elite group within the organization (Renaud et al. 2016). SAM does not emphasize the importance of the stream of Strategy as Practice (SaP). SaP defines strategy as some- 
thing for which actors are responsible and is not simply the content or the action plan resulting from a decision. Instead, SaP breaks away from conventional literature on the strategy that focuses primarily on top managers and challenges the notion that only one elite group within an organization can act strategically (Renaud et al. 2016). Secondly, SAM is an abstract "black box" that may not reflect its corresponding environmental complexity. As a result, SAM might overlook the organizational reality, and managers might face difficulty in effectively appropriating its dimensions (Avison et al. 2004). Renaud et al. (2016) later also pinpointed that due to SAM's high level of abstraction, it might lack an approximate representation of practical reality. Finally, SAM's is virtually designed exclusively for top managers. This model presumes that if the managers follow the model's rational prescriptions, organizational performance should improve (but often does not) (Renaud et al. 2016). Moreover, SAM emphasizes the technical aspect and underestimates the importance of the social aspect of the IS because of its theoretical abstractions. Interestingly, at the time of the SAM model's initial proposal, an IS was hardly considered a socio-technical system (Renaud et al. 2016). Today, however, studies find that ISs, users, and organizations are intrinsically embedded and interrelated since each of them shapes the others. Hence, emerging approaches need to consider SaP, low level of abstraction, and, similar to the abovementioned, consider IS as a socio-technical system to address the limitations of SAM and improve the applicability of MLs for achieving operational alignment.

Finally, the studies of operational alignment that focus on social antecedents overlook the need for a multi-dimensional understanding of operational alignment and how the ISs meet business requirements. Firstly, alignment must be assessed with a multi-dimensional model (Hanson et al. 2011). Our assessment of the existing literature, focused on identifying social antecedents and their effect on operational alignment (e.g., Wagner et al. 2014; Zhou et al. 2018; Bagheri et al. 2019), shows that these studies are particularly focused on the social antecedents and did not consider the other antecedents (i.e., dimensions) of operational alignment. Additionally, these studies consider how social antecedents affect operational alignment, regardless of how ISs meet business requirements. Therefore, there is a need for approaches that not only consider operational alignment as a multi-dimensional concept but also emphasize how ISs meet the business requirements in achieving operational alignment.

Consequently, the discussed shortcomings of the two fundamental premises of ML approaches and approaches considering only the social antecedents result in limitations in their applicability for achieving operational alignment. In this study, we posit that the underlying rationale for these limitations stems from the conceptualization of operational alignment and empirical methodology. Given the research gap mentioned above, we use a bottom-up approach to reconceptualize operational alignment, where elements and dimensions of operational alignment are explored, and the reality and practice at the operational level are different from that of the strategic level.

\section{Research methodology}

\subsection{Grounded Theory and approaches}

In this study, we used GT to determine the right level of abstraction for describing BPs and ISs in achieving operational alignment. GT is a qualitative research methodology, which transcends survey and content analysis techniques by using conceptualization (Lings and Lundell 2005). GT is based on a bottom-up approach and focuses on answering questions like "What is going on in an area of research?" by generating formal or substantive theory (Corbin and Strauss 2008). Although GT has been initially used in social studies, it is also a useful method for a wide range of IS field topics (Wiesche et al. 2017). There are two main reasons for selecting GT as the most appropriate research methodology for conducting this study. Firstly, GT has a high capacity for exploring and interpreting complex and multifaceted phenomena (Corbin and Strauss 2008), such as operational alignment with multiple dimensions and elements. Secondly, this research considers an IS to be a socio-technical system. GT enables the disentanglement of the social processes underlying human interactions (Glaser and Holton 2007) and, therefore, is best suited for studying issues with a socio-technical nature.

We used an emergent approach in this study. The emergent approach is flexible and unstructured. In the case that the previous studies are insufficient, the emergent approach extracts a theory from the data rather than imposing a theory on the data (Glaser and Holton 2007). We used the emergent approach for two main reasons. Firstly, this approach is instrumental in constructing a novel perspective on a well-known area (Stern 1994), which was our research goal. Secondly, the emergent approach is suitable where the work is not driven by a hypothesis up-front and the goal of the study is to establish a conceptual framework grounded in data (Glaser and Holton 2004). In this research, we did not predefine assumptions; we investigated participants' main concerns in operational alignment to discover how they can be resolved. Here, we used the emergent approach to obtain a new perspective on operational alignment and establish a conceptual framework grounded in data.

\subsection{The empirical context}

We conducted this study at top public universities (TPUs) in Iran for the following reasons. First and foremost, TPUs have a long-standing need for operational alignment 
and CIOs are concerned about operational alignment. Secondly, TPUs meet the foundational requirements for operational alignment investigation and implementation as (1) TPUs are leaders among universities in the Middle East in developing IT/IS capabilities and (2) TPUs widely use ISs at various levels and have effective BP management. Departments of BPs and ISs at TPUs are separate, with each having independent plans and responsibilities. As a result, TPUs not only have the need for operational alignment but also meet the foundational requirements for the implementation of operational alignment. Therefore, exploration of the elements and dimensions for appropriate actualization of operational alignment is facilitated at TPUs.

\subsection{Sampling and data collection}

To carry out this study, we targeted experts in the field of business-IS alignment. Initially, we contacted a few experts familiar with business-IS alignment via email and phone to seek their consent for participation. To identify more qualified experts, we employed snowball sampling, which is a method of expanding the sample by asking one informant or participant to recommend others for interviewing (Stern 1994). Furthermore, due to (1) business-IS alignment being multifaceted (different antecedents related to different fields) and (2) data triangulation being necessary in qualitative research (Corbin and Strauss 2008), we selected the experts from different fields (i. e., IS, BP, and operational alignment) and groups. We categorized experts into either academic researchers or managers and senior experts (i.e., policymakers in both IS and BP). The managers and senior experts are individuals who have responsibilities in five different sectors at the TPUs (1) learning, (2) administrative and financial affairs, (3) planning and development resources, (4) research, and (5) the cultural, social, and student area.

The most appropriate data collection method in GT is semi-structured interviewing (Glaser and Holton 2007), which we employed in the present study. Based on theoretical sampling in GT, we performed 28 semi-structured, in-depth interviews. Theoretical sampling is non-probable, purposive, and subject to the researchers' judgment (Glaser and Hon 2005). The basic approach of theoretical sampling is to identify the new groups or subgroups that should be chosen for the next stage of data collection (Glaser 2008) to fill the emergent gaps in the theory during the coding process (Glaser and Holton 2004).

\subsection{Data analysis}

We analyzed data using the coding process of the emergent approach based on substantive coding (open and selective) and theoretical coding. Substantive and theoretical coding are not distinct stages in the interpretation process; rather, they are different ways to work with the textual data that the researchers may dislocate or integrate. The interpretation process begins with open coding and uses selective and theoretical coding during the final steps of analysis.

In terms of tool support, we used MAXQDA 10, a powerful computer-assisted qualitative data analysis software (Schonfelder 2011), to analyze and manage the GT-required steps.

\section{Results}

\subsection{Open coding}

During the open coding step, we extracted open codes and concepts. At first, we obtained 321 open codes. Then, we categorized open codes by their similarities and differences. We extracted and organized 106 concepts by domain: 45 concepts in the BP domain and 61 concepts in the IS domain.

\subsection{Selective coding}

We filtered, separated, unified, and regulated the resulted concepts from open coding during the selective coding step. This was achieved by reducing the initial number of codes to an explanatory framework of high-level categories (i.e., dimensions). We selected dimension names based on in vivo code matching that uses the interviewees' statements to ensure close support of the findings by the data. In addition, the name of a dimension was selected to connect the related or similar concepts. The dimensions, therefore, have higher conceptual strength than concepts because they link many of the concepts. Using selective coding, we categorized the 45 concepts identified in the BP domain into 11 dimensions and categorized 61 concepts in the IS domain into four dimensions. We describe each dimension obtained from selective coding in BP and IS domains in the following two sections. Hereafter, concepts are referred to as the "elements", or constituents, of their respective identified dimension.

\subsubsection{Dimensions in the BP domain}

The dimensions in the BP domain consist of the development of ISs to support each of the BP functions. BP functions are learning management, research management, strategic management, quality management, student services management, social and cultural management, communication management, assets management, human resource management (HRM), financial resource management, and information and communication technology (ICT) management. In the interest of conciseness, only 
one of the dimensions in the BP domain is explained here, described by a selected quotation from the interviewees.

Dimension BP1: Development of ISs to support learning management. In response to questions about the compatibility of ISs with BPs, most respondents argued that it would not be possible to develop ISs without considering ISs in supporting the key learning management processes at the university (e. g., Expert E6).

From their perspective, the use of ISs in the administrative and teaching services, learning planning, admission, learning assessment, and termination of study would improve services at the TPUs and provide the TPUs with adequate information for refining the decision outcomes concerning learning management.

The development of a comprehensive learning program is dependent on the presence of activities such as the management of learning units, the planning of learning activities and documentation, and the modification of learning regulations. In addition, ISs are instrumental in providing essential information for the fulfilment of these activities. (Expert E6)

\subsubsection{Dimensions in the IS domain}

Dimensions derived from selective coding in the IS domain include the development of BPs commensurate with the IS capabilities, namely strategic, management, knowledge-based, and operational capabilities. For brevity, only one of the dimensions in the IS domain is explained here and described by a selected quotation from the interviewees.

Dimension IS1: Development of BP commensurate with the strategic capabilities of IS. The majority of experts argue that university processes should be designed by utilizing the IS's strategic capabilities to create and improve strategic benefits (e. g., Expert E4).

Strategic capabilities allow environmental assessments and analysis of the business for identifying long-term strategic goals. For instance, collecting and processing various student data could identify a more effective and individualized student learning processes. Strategic capabilities include flexible and diverse internal and external resources that would enable change, as well as timely availability of information to analyze environmental opportunities and threats for the business and the strengths and weaknesses of the business.

In my opinion, the sustainable and competitive advantage of the university is contingent upon improving the design of the educational services to use the capabilities of the IS for reducing the current service costs and enhancing service provisions. Further, we all know that university processes are continually changing due to environmental changes, and therefore, the flexibility of the ISs supports our ability to respond to these changing processes. (Expert E4)

\subsection{Theoretical coding}

To develop the theoretical framework, we defined the main categories extracted from the coding steps and their relationships based on Glaser's type family. The type family presents the main categories and their relationships based on their types, forms, kinds, and styles (Glaser 2008). In this regard, first, based on related literature, we identified the types of BP functions of the extracted dimensions in the BP domain (Section 4.3.1) and the types of IS capabilities of obtained dimensions in the IS domain (Section 4.3.2). Then, we reviewed all the memos generated throughout the study to relate and enrich the main categories in the presented framework (Section 4.3.3).

\subsubsection{Types of BP functions}

We categorized the BP functions in our study based on previous literature (Porter and Millar 1985; Bucher et al. 2009; Boguslauskas and Kvedaraviciene 2009). After we reviewed the open codes, concepts (elements), and categories (dimensions) several times, we grouped BP functions into two main types: primary and support. The primary functions are defined as functions that focus on developing products, distributing them, and offering after-sale services on products. In contrast, the support functions are defined as functions that provide inputs and infrastructure that enable the primary functions (Porter and Millar 1985).

In comparison, management functions, business functions, and support functions are value-adding functions defined by Bucher et al. (2009) that can be paralleled to the Porter and Millar's categorization of primary and support functions. In this categorization, management functions comprise all fundamental management activities dealing with an organization's development, design, leadership, and control. Business functions are defined as functions that represent the actual execution of all market-side operations, focused on the immediate creation of consumer value. And finally, support functions are defined as functions that involve the infrastructure provision and internal services production, required for efficient and effective execution of the processes. Therefore, the primary functions defined by Porter and Miller (1985) are virtually the management and business functions as described by $\mathrm{Bu}-$ cher et al. (2009) because both management and business functions are focused on product development directly or indirectly. Specifically, while management functions indirectly contribute to consumer value, business functions are directly involved in this process as well as the development of the product, market-sided activities, and after-sale services. The support functions in the study of Bucher et al. (2009) are, in turn, equivalent to the support functions in the study of Porter and Miller (1985) because by both definitions, these are the functions that provide inputs and 
support the infrastructures for implementation of other functions.

Finally, business functions can be categorized into core and non-core functions. Core business functions relate most directly to the basic business of the organization and represent the key organizational activities (Boguslauskas and Kvedaraviciene 2009). Therefore, core business functions are the critical business operation activities that an organization is founded on, and these functions are the main source of organizational profits and success. In comparison, non-core business functions exist only to facilitate the business (Weerakkody et al. 2003).

Thus, based on the discussed categorizations above (Porter and Millar 1985; Bucher et al. 2009; Boguslauskas and Kvedaraviciene 2009), in our study, the types of BP functions are primary and support functions, where primary functions consist of management functions, core business functions, and non-core business functions. Appendix $\mathrm{B}$ shows the different types of BP functions.

\subsubsection{Types of IS capabilities}

We categorized the IS capabilities in our study based on a four-level pyramid of ISs (O'Brien 2000) and STS theory (Bostrom and Heinen 1977). Regarding the four-level pyramid of ISs, this model identifies several ISs and links their capabilities to the four organizational levels: strategic, management, knowledge, and operational. In our study, we similarly described IS capabilities based on these four levels. ISs at the strategic level focus on strategic issues and long-term trends. The ISs at the management level monitor, control, and make decisions to show how the organization is performing. ISs at the knowledge level create, distribute, and share knowledge. And the ISs at the operational level record initial activities and transactions of organizations.

The STS theory considers an IS as a socio-technical system consisting of social and technical subsystems (Bostrom and Heinen 1977) with four interacting components: (1) actor, (2) structure, (3) task, and (4) technology (Lyytinen and Newman 2008). (1) Actors are the entities (individuals, organizations, consumers, policymakers, etc.) who make decisions and are involved in processes by performing different roles. (2) The structure includes both the normative aspect, that is, values, norms, and general role expectations, and the behavioural aspect, that is, the patterns of behaviour as actors communicate, exercise authority, or work. The structure covers one or more of three systems: the authority system, the workflow system, and the communication system. The authority system shows the required regulations, standards, and rules for facilitating tasks. The workflow system is related to standardization for tasks. And the communication system refers to norms and patterns of behaviour in communication. (3) The task component elucidates how the work gets done within the organization. (4) Technology denotes technical infrastructure required, including network, hardware, and software (Lyytinen and Newman 2008). The interaction of the components is the actor doing (creating or performing) tasks associated with (producing or using) technology and connecting to (creating or under) a specific structure.

Following the abovementioned studies (O'Brien 2000; Bostrom and Heinen 1977; Lyytinen and Newman 2008), we described types of IS capabilities based on four levels of ISs. We considered ISs at each level as a socio-technical system with its own components. Appendix C shows the different types of IS capabilities.

\subsubsection{Relating BP functions and IS capabilities: FunCaps framework}

We reconceptualized operational alignment based on the main categories and their relationship in a novel "Functions and Capabilities (FunCaps) framework" to show the combinations of BP functions and IS capabilities that need to be aligned to achieve operational alignment. We studied the open codes, concepts, dimensions, and types of BP functions and IS capabilities several times to identify the main categories (the types of BP functions and IS capabilities) and their relationships. The main categories and their relationships surfaced to achieve the alignment between BP functions (primary and support) and IS capabilities (strategic, management, knowledge-based, and operational). These main categories detect the conceptual relations that connect all higher-level dimensions and all elements and dimensions derived in the coding process refer to them. Finally, based on the main categories and their relationships, we reconceptualized operational alignment as shown in Figure 1.

The FunCaps framework provides a visual framework to determine the combinations of BP functions and IS capabilities that need to be aligned to achieve operational alignment (Figure 1). For instance, for alignment of core business functions and IS capabilities, learning management and research management need to be aligned with all four types of IS capabilities (strategic capabilities, management capabilities, knowledge-based capabilities, and operational capabilities).

\section{Discussion and integration with existing frameworks}

\subsection{Positioning the findings in foundational business-IS alignment terminologies}

We positioned our findings based on the four fundamental considerations of business-IS alignment that other 
researchers have reached a consensus on, despite the differences in terminology used for business-IS alignment. Alignment has been discussed since 1970s (Renaud et al. 2016), and different researchers have described alignment with terms such as integration, fit, bridge, harmony, and linkage (Avison et al. 2004). The diversity in the terminology used for definition and exploration of alignment highlights the time-dependent understanding of alignment in the field. However, most researchers acknowledge busi-
ness-IS alignment as a continuous process involving four fundamental considerations: (1) integration level (Henderson and Venkatraman 1993), (2) integration direction (Teo and King 1997), (3) the perspective of fit (Venkatraman 1989), and (4) categories of misfit (Strong and Volkoff 2010). Table 1 illustrates a summary of the positioning of our findings in the abovementioned foundational considerations.

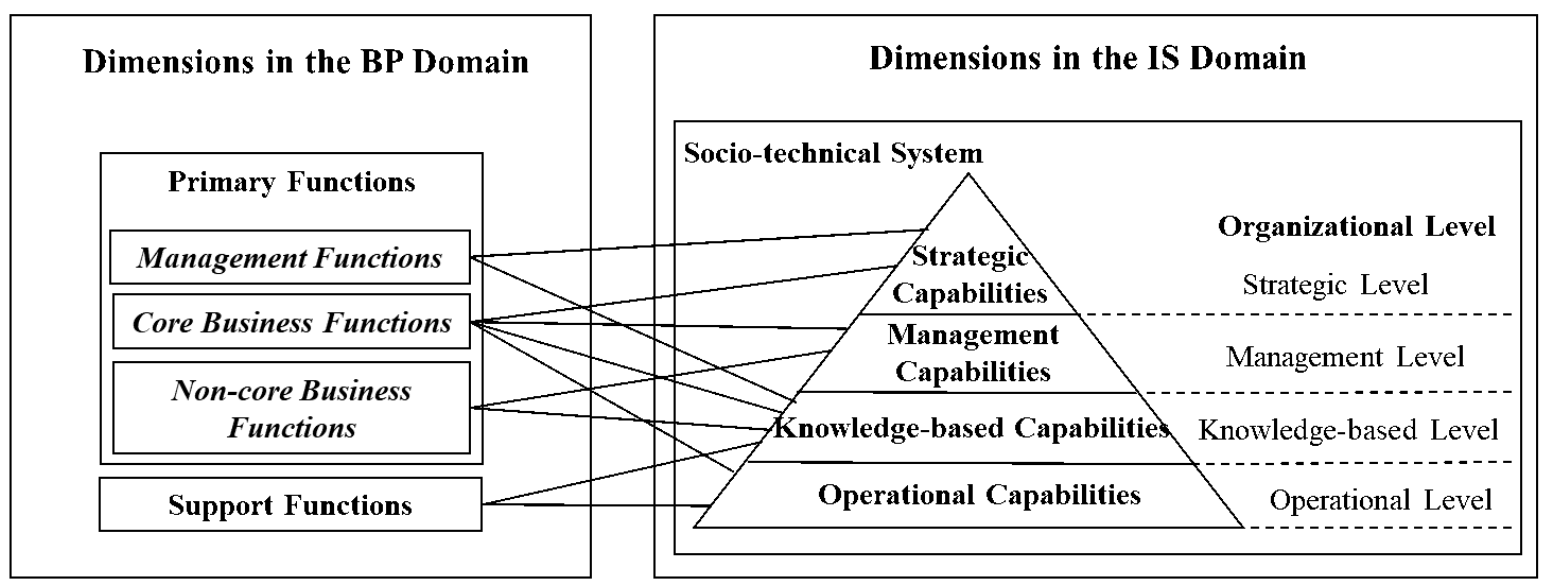

Legend: lines betweeen dimensions mean alignment

Figure 1: The FunCaps framework for operational alignment

In comparison to SAM, the FunCaps framework aims to actualize and reconceptualize operational alignment to overcome the limitations of SAM. The FunCaps framework and SAM capture the alignment between processes and infrastructures for business and IS domains. However, the FunCaps framework goes further than SAM by opening up the operational integration boxes and their relationships in SAM and addressing three of SAM's shortcomings. Firstly, FunCaps framework, unlike SAM, emphasizes the importance of Strategy as Practice (SaP) by describing the types of IS capabilities based on a four-level pyramid of ISs (O'Brien 2000). Each level is considered a socio-technical system, where strategy at each level is not considered solely as an action plan developed by the top business management. Instead, in this socio-technical system, actors at all four levels of the pyramid are responsible for strategy.

Secondly, FunCaps is fine-grained and, hence, shows the practical reality of the organization. This framework visualizes and reconceptualizes operational alignment based on low level, precise, and well-defined operational concepts. As such, FunCaps provides a useful way for policy makers, managers, and senior IS experts to adopt its dimensions and elements in both BP and IS domains.
Thirdly, FunCaps considers an IS as a socio-technical system and describes IS capabilities based on its components (actor, structure, task, and technology). The mutual interaction between these components, in turn, results in creating and modifying IS capabilities. Figure 3 shows the integration of the FunCaps framework and SAM.

\section{Conclusion and future research}

Achievement of Operational alignment has been a key challenge for organizations in recent decades (Kappelman et al. 2019) due to the limitations of existing models and frameworks. Operational alignment enables organizations to not only make the BPs implementation feasible but also to increase the utilization of ISs. In addition, it helps the ISs to be business-centered and to adjust the requirements for developing BPs (Tallon et al. 2016). Multiple models and frameworks exist in the field of business-IS alignment. In practice, however, they have not been effective for the realization of operational alignment due to three major limitations. Firstly, most existing models are coarse-grained as they focus on the strategic level of alignment. These models do not consider the discrepancies between the two 
Table 1: Positioning the findings in foundational considerations of business-IS alignment

\begin{tabular}{|c|c|c|c|c|}
\hline Reference & \multicolumn{2}{|c|}{ Foundational considerations } & Description & $\begin{array}{l}\text { This } \\
\text { paper }\end{array}$ \\
\hline \multirow{2}{*}{$\begin{array}{l}\text { Henderson } \\
\text { and Ven- } \\
\text { katraman } \\
\text { (1993) }\end{array}$} & \multirow{2}{*}{$\begin{array}{l}\text { Integration } \\
\text { level }\end{array}$} & Strategic & $\begin{array}{l}\text { The link between the business strategies and IS strategies, } \\
\text { reflecting the external components of the business }\end{array}$ & \\
\hline & & Operational & $\begin{array}{l}\text { The link between business infrastructures and processes, } \\
\text { and IS infrastructures and processes, dealing with internal } \\
\text { components of the business }\end{array}$ & $*$ \\
\hline \multirow{4}{*}{$\begin{array}{l}\text { Teo and } \\
\text { King } \\
(1997)\end{array}$} & \multirow{4}{*}{$\begin{array}{l}\text { Integration } \\
\text { direction }\end{array}$} & Administrative & Development of business and IS, based on separate planning & \\
\hline & & Sequential & $\begin{array}{l}\text { One-way planning process and IS, focused primarily on pro- } \\
\text { viding support for business }\end{array}$ & \\
\hline & & Reciprocal & $\begin{array}{l}\text { Two-way planning process and IS, playing a role in both sup- } \\
\text { porting and influencing business }\end{array}$ & $*$ \\
\hline & & Full integration & $\begin{array}{l}\text { Concurrent development of business and IS in the same inte- } \\
\text { gration planning process }\end{array}$ & \\
\hline \multirow{6}{*}{$\begin{array}{l}\text { Venka- } \\
\text { traman } \\
(1989)\end{array}$} & \multirow{6}{*}{$\begin{array}{l}\text { Perspective } \\
\text { of fit }\end{array}$} & Moderation & $\begin{array}{l}\text { Conceptualizing alignment as the interaction between two } \\
\text { variables (e.g., strategic orientation and strategic IS manage- } \\
\text { ment), and studying their interactional effect on firm perfor- } \\
\text { mance }\end{array}$ & \\
\hline & & Mediation & $\begin{array}{l}\text { Considering alignment as an intervening variable between } \\
\text { antecedent variables such as strategic orientation and con- } \\
\text { sequent variables such as firm performance }\end{array}$ & \\
\hline & & Matching & Defining alignment as a match between the two variables & * \\
\hline & & Covariation & $\begin{array}{l}\text { Adopting a conceptualization based on the internal consis- } \\
\text { tency among a set of underlying related variables }\end{array}$ & \\
\hline & & Profile deviation & $\begin{array}{l}\text { Assuming an ideal profile exists, i.e., ideal values of variables } \\
\text { are the values of high performers }\end{array}$ & \\
\hline & & Gestalt & $\begin{array}{l}\text { Conceptualizing alignment as frequently recurring clusters of } \\
\text { attributes }\end{array}$ & \\
\hline \multirow{6}{*}{$\begin{array}{l}\text { Strong } \\
\text { Volkoff } \\
(2010)\end{array}$} & \multirow{6}{*}{$\begin{array}{l}\text { Categories } \\
\text { of misfit }\end{array}$} & Functionality & $\begin{array}{l}\text { Occurring when BP executions, using the enterprise system } \\
\text { (ES), lead to reduced efficiency or effectiveness }\end{array}$ & $*$ \\
\hline & & Data & $\begin{array}{l}\text { Resulting from data quality issues (such as inaccuracy) caused } \\
\text { by data or data characteristics stored in, or needed by, the ES }\end{array}$ & \\
\hline & & Usability & $\begin{array}{l}\text { Occurring when the required interactions with the ES for task } \\
\text { execution are cumbersome or confusing }\end{array}$ & \\
\hline & & Role & $\begin{array}{l}\text { Arising from inconsistencies between the roles in the ES and } \\
\text { the available skills }\end{array}$ & \\
\hline & & Control & $\begin{array}{l}\text { Stemming from excessive or insufficient controls within the } \\
\text { ES-embedded controls }\end{array}$ & \\
\hline & & Culture & $\begin{array}{l}\text { Resulting from contradictions between ES requirements and } \\
\text { organizational norms }\end{array}$ & \\
\hline
\end{tabular}

levels of alignment (strategic and operational). Secondly, existing studies neglect the socio-technical nature of the IS. Thirdly, previous studies are focused on identifying social antecedents and their effect on operational alignment without considering how ISs meet business requirements in achieving operational alignment. This research determined the right level of abstraction to describe BPs and ISs for achieving operational alignment and address the current discussed gaps in the existing studies. We adopted GT as a bottom-up approach to reconceptualize operational alignment and used an adaptive approach in the description of BPs and ISs instead of confirming or imposing a theory on business-IS alignment. The result was the FunCaps framework. This framework considers differences between strategic and operational alignment and reconceptualizes operational alignment based on oper- 


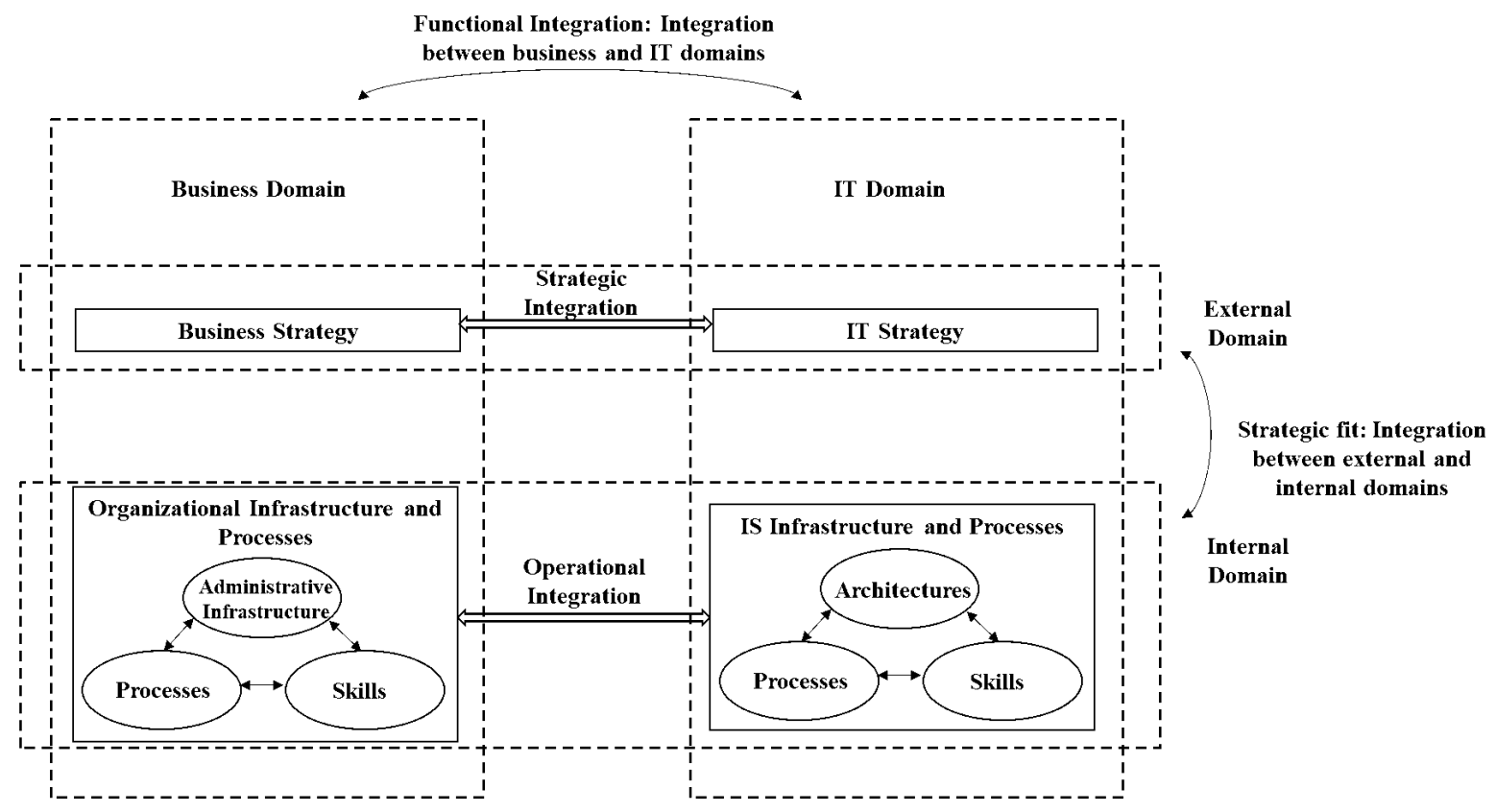

Figure 2: SAM (From Henderson and Venkatraman 1993)

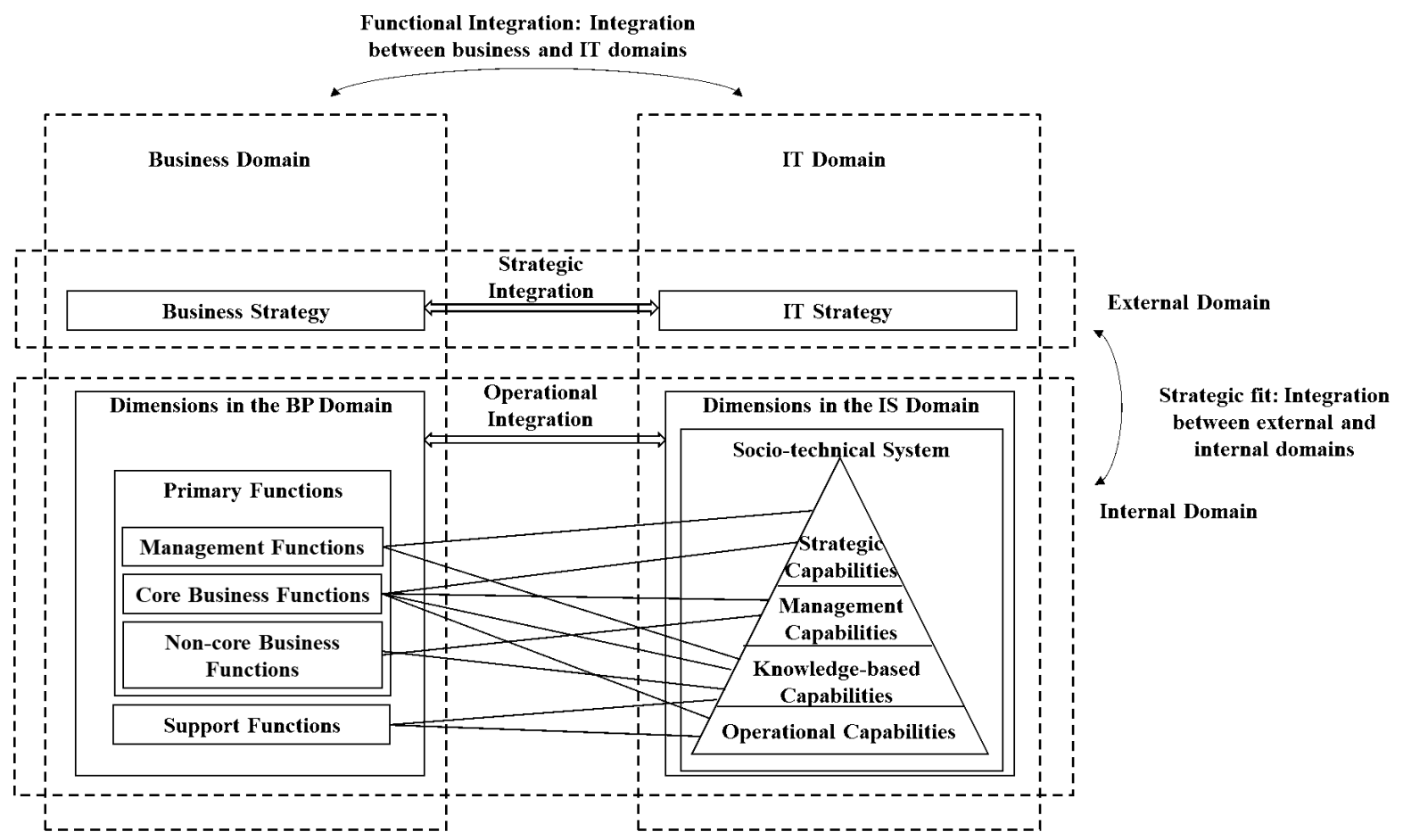

Legend: lines betweeen dimensions mean alignment

Figure 3: The integration of FunCaps framework and SAM 
ational planning and reciprocal integration. Thus, FunCaps is a fine-grained framework that translates high-level, strategic concepts into low level, precise, and well-defined operational concepts. (i.e., BP functions and IS capabilities). FunCaps, in addition, establishes the broader picture of the operational alignment by considering an IS to be a socio-technical system.

This study has three main limitations that can offer opportunities for future studies in this area. The first is the focus of TPUs in Iran. Broader research at educational institutions in other countries can add to the number of experts and enhance the results of the research. The second limitation is the neglect of the other two levels of alignment (strategic and tactical). Future studies might identify the dimensions and elements of alignment at all levels and provide a model for achieving business-IS alignment at all three levels. The third limitation arises from the focus on STS theory. To describe the types of IS capabilities and situate them in STS theory, we did not explicitly assess the interaction of components (actor, structure, task, and technology) in this study. Future studies can further explore this socio-technical approach toward operational alignment for both BP and IS domains and consider the interaction between the components.

\section{Literature}

Alavi, M., \& Yoo, Y. (1995). Productivity gains for BPR. Information Systems Management, 12(4), 43-47. https://doi.org/10.1080/07399019508963002

Alsudiri, T., Al-Karaghouli, W., \& Eldabi, T. (2013). Alignment of large project management process to business strategy: A review and conceptual framework. Journal of Enterprise Information Management, 26(5), 596615. https://doi.org/10.1108/JEIM-07-2013-0050

Attaran, M. (2003). Information technology and business process redesign. Business Process Management Journal, 9(4), 440-458. https://doi. org/10.1108/14637150310484508

Aversano, L., Grasso, C., \& Tortorella, M. (2016). Managing the alignment between business processes and software systems. Information and Software Technology,72, 171-188. https://doi.org/10.1016/j.infsof.2015.12.009

Avison, D., Jones, J., Powell, P., \& Wilson, D. (2004). Using and Validating the Strategic Alignment Model. Journal of Strategic Information Systems, 13(3), 223246. https://doi.org/10.1016/j.jsis.2004.08.002

Bagheri, S., Kusters, R.J., Trienekens, J.J.M., \& Grefen, P.W.P.J. (2019). A Reference Model-Based User Requirements Elicitation Process: Toward Operational Business-IT Alignment in a Co-Creation Value Network. Information and Software Technology, 111, 7285. https://doi.org/10.1016/j.infsof.2019.03.012

Bergeron, F., Raymond, L., \& Rivard, S. (2004). Ideal
Patterns of Strategic Alignment and Business Performance. Information \& Management, 41(8), 10031020, https://doi.org/10.1016/j.im.2003.10.004

Boguslauskas, V., \& Kvedaraviciene, G. (2009). Difficulties in identifying Company's Core Competencies and Core Processes. Engineering Economics, 62(2), 75-80.

Bostrom, R.P. \& Heinen, J.S. (1977). MIS problems and failures: a socio-technical perspective. Part I: the causes. MIS Quarterly, 1(3), 17-32, https://doi. org/10.2307/248710

Bucher, T., Gericke, A., \& Sigg, S. (2009). Process-centric business intelligence. Business Process Management Journal, 15(3), 408-429, https://doi. org/10.1108/14637150910960648

Cibran, M.A. (2009). Translating BPMN models into UML activities. In Business Process Management Workshops on pp. 236-247, Springer Berlin Heidelberg.

Corbin, J. \& Strauss, A. (2008). Basics of Qualitative Research: Techniques and Procedures for Developing Grounded Theory. Sage Publications, Los Angeles. https://doi.org/10.1177/1094428108324514

Cram, W. (2012). Aligning organizational values in systems development projects. Management Research Review, 35(8), 709-726. https://doi. org/10.1108/01409171211247703

De Castro, V., Marcos, E., \& Vara, J. M. (2011). Applying CIM-to-PIM model transformations for the service-oriented development of information systems. Information and Software Technology,53(1), 87-105. https://doi.org/10.1016/j.infsof.2010.09.002

Doumi, K., Baina, S., \& Baina, K. (2013). Strategic business and IT alignment: representation and evaluation. Journal of Theoretical\& Applied Information Technology, 47(1), 41-52.

Elvesater, B., Panfilenko, D., Jacobi, S., \& Hahn, C. (2010). Aligning business and IT models in service-oriented architectures using BPMN and SoaML. In Proceedings of the First International Workshop on Model Driven Interoperability, pp. 61-68, ACM, https://doi. org/10.1145/1866272.1866281

Frankova, G., Séguran, M., Gilcher, F., Trabelsi, S., Dörflinger, J., \& Aiello, M. (2011). Deriving business processes with service level agreements from early requirements. Journal of Systems and Software, 84(8), 1351-1363, https://doi.org/10.1016/j.jss.2011.03.077

Gehlert, A., Bramsiepe, N., \& Pohl, K. (2008). Goal-driven alignment of services and business requirements. In Service-Oriented Computing: Consequences for Engineering Requirements, SOCCER'08, International Workshop on pp. 1-7, IEEE, https://doi.org/10.1109/ SOCCER.2008.5

Gerow, J., Grover, V., \& Thatcher, J. (2016). Alignment's Nomological Network: Theory and Evaluation. Information \& Management, 53(5), 541-553, https://doi. org/10.1016/j.im.2015.12.006

Glaser, B.G. (2008). Conceptualization: on theory and theorizing using grounded theory. International Journal of Qualitative Methods, 1(2), 23-38, https://doi. 
org $/ 10.1177 / 160940690200100203$

Glaser, B. G., \& Holton, J. (2004). Remodeling Grounded Theory. Forum: Qualitative Social Research, 5(2), 1-17, https://doi.org/10.17169/fqs-5.2.607

Glaser, B.G. \& Holton, J. (2007). Remodeling Grounded Theory. Historical Social Research, 19(32), 47-68, https://www.jstor.org/stable/40981068

Glaser, B. G., \& Hon. (2005). Staying Open: The Use of Theoretical Codes in Grounded Theory. The Grounded Theory Review, 5(1), 1-20.

Grover, V., \& Lyytinen, K. (2015). New State of Play in Information Systems Research: The Push to the Edges. MIS Quarterly, 39(2), 271-296, https://doi. org/10.25300/MISQ/2015/39.2.01

Han, F., Moller, E., \& Berre, A.J. (2009). Organizational interoperability supported through goal alignment with BMM and service collaboration with SoaML. In Interoperability for Enterprise Software and Applications China, IESA'09, International Conference on pp. 268274, IEEE, 10.1109/I-ESA.2009.55

Hanson, J.D., Melnyk, S.A., \& Calantone, R.A. (2011). Defining and measuring alignment in performance management. International Journal of Operations \& Production Management, 31(10), 1089-1114, https:// doi.org/10.1108/01443571111172444

Henderson, J. C., \& Venkatraman, N. (1993). Strategic Alignment: Leveraging Information Technology for Transforming Organizations. IBM Systems Journal, 32(1), 472- 484, https://doi.org/10.1147/sj.382.0472

Hinkelmann, K., Gerber, A., Karagiannis, D., Thoenssen, B., Merwe, A., \& Woitsch, R. (2016). A New Paradigm for the Continuous Alignment of Business and IT: Combining Enterprise Architecture Modelling and Enterprise Ontology. Computers in Industry, 79, 77-86, https://doi.org/10.1016/j.compind.2015.07.009

Kanter, J. (1996). Guideline for attaining information literacy. Information Strategy, 12(3), 6-11.

Kappelman, L., Torres, R., McLean, E., Maurer, Ch., Johnson, V., \& Kim, K. (2019). The 2018 SIM IT issues and trends study. MIS Quarterly Executive, 18(1), 51-84, https://aisel.aisnet.org/misqe/vol18/iss1/7

Kappelman, L., Johnson, V., Maurer, Ch., McLean, E., Torres, R. \& Nguyen, Q. (2018). The 2017 SIM IT issues and trends study. MIS Quarterly Executive, 17(1), 53-88, https://aisel.aisnet.org/misqe/vol17/iss1/6

Karpovsky, A., \& Galliers, R. D. (2015). Aligning in practice: from current cases to a new agenda. Journal of Information Technology, 30(2), 136-160, https://doi. org/10.1057/jit.2014.34

Kaul, M., Storey, V.C., \& Woo, C. (2017). A Framework for Managing Complexity in Information Systems. Journal of Database Management, 28(1), 31-42, https://doi.org/10.4018/JDM.2017010103

Kotusev, S. (2020). The Hard Side of Business and IT Alignment. IT Professional, 22(1), 47-55, https://doi. org/10.1109/MITP.2019.2912136

Kraiem, H.K., Jamil, D. \& Zuhoor, A.K. (2014). Mapping from MAP Models to BPMN Processes. Journal of Software Engineering, 8(4), 252-264, https://doi. org/10.3923/jse.2014.252.264

Lederer, A., \& Mendelow, A. (1989). Co-ordination of Information Systems Plans with Business Plans. Journal of Management Information Systems, 6(2), 5-19, https://doi.org/10.1080/07421222.1989.11517854

Lester, D. L., \& Parnell, J. A. (2002). Aligning factors for successful organizational renewal. Leadership \& Organization Development Journal, 23(2), 60-67, https:// doi.org/10.1108/01437730210419189

Levstek, A., Hovelja, T., \& Pucihar, A. (2018). IT Governance Mechanisms and Contingency Factors: Towards an Adaptive IT Governance Model. Organizacija, 51(4), 286-310, https://doi.org/10.2478/orga-20180024

Li, Z., Zhou, X., Gu, A., \& Li. Q. (2015). A complete approach for CIM modelling and model formalizing. Information and Software Technology, 65, 39-55, https:// doi.org/10.1016/j.infsof.2015.04.003

Lings, B., \& Lundell, B. (2005). On the adaptation of grounded theory procedures: Insights from the evolution of the $2 \mathrm{G}$ method. Information Technology and People, 18(3): 196-211, https://doi. org/10.1108/09593840510615842

Luftman, J. (2003). Assessing IT/business alignment. Information Systems Management, 20(4), 9-15, https:// doi.org/10.1201/1078/43647.20.4.20030901/77287.2

Luftman, J., Lyytinen, K., \& Ben Zvi, T. (2017). Enhancing the measurement of information technology (IT) business alignment and its influence on company performance. Journal of Information Technology, 32(1), 26-46, https://doi.org/10.1057/jit.2015.23

Lyytinen, K., \& Newman, M. (2008). Explaining information systems change: a punctuated socio-technical change model. European Journal of Information Systems, 17(6), 589-613, https://doi.org/10.1057/ ejis. 2008.50

Malshe, A., Friend, S. B., Al-Khatib, J., Al-Habib, M., \& Al-Torkistanid, H. (2017). Strategic and operational alignment of sales-marketing interfaces: Dual paths within an SME configuration. Industrial Marketing Management, 66, 145-158, https://doi.org/10.1016/j. indmarman.2017.08.004

O'Brien, J.A. (2000). Introduction to Information Systems: Essential for the Internetworked Enterprise. 9th ed., Irwin/McGraw-Hill, New York, NY.

Pantazi, M.A., \& Georgopoulos, N.B. (2006). Investigating the Impact of Business process- Competent Information Systems (ISs) on Business Performance. Managing Service Quality: An International Journal, 16(4), 421-434, https://doi.org/10.1108/09604520610675739

Porter, M., \& Millar, V. (1985). How Information Gives You Competitive Advantage. Harvard Business Review, 63(4) 149-174.

Preston, D., \& Karahanna, E. (2009). Antecedents of IS Strategic Alignment: A Nomo logical Network. Information Systems Research, 20(2), 159-179, http://www. jstor.org/stable/23015478 
Pyburn, P.J. (1983). Linking the MIS plan with corporate strategy: an exploratory study. MIS Quarterly, 7(2), 1-14, https://doi.org/10.2307/248909

Rahimi, F., Moller, Ch., \& Hvam, L. (2016). Business Process Management and IT Management: The Missing integration. International Journal of Information Management,36, 142-154, https://doi.org/10.1016/j.ijinfomgt.2015.10.004

Reich, B., \& Benbasat, I. (2000). Factors that Influence the Social Dimension of Alignment between Business and Information Technology Objectives. MIS Quarterly, 24(1), 81-113, https://doi.org/10.2307/3250980

Renaud, A., Walsh, I., \& Kalika, M. (2016). Is SAM Still Alive? A Bibliometric and Interpretive Mapping of the Strategic Alignment Research Field. The Journal of Strategic Information Systems, 25(2), 75-103, https:// doi.org/10.1016/j.jsis.2016.01.002

Schonfelder, W. (2011). CAQDAS and qualitative syllogism logic-NVivo 8 and MAXQDA 10 compared. Forum Qualitative Social Research, 12(1) Art. 21, http:// nbn-resolving.de/urn:nbn:de:0114-fqs1101218.

Schwarz, A., Kalika, M., Kefi, H., \& Schwarz, C. (2010). A Dynamic Capabilities Approach to Understanding the Impact of IT-Enabled Businesses Processes and IT-Business Alignment on the Strategic and Operational Performance of the Firm. Communications of the Association for Information Systems, 26(1), 57-84, https://doi.org/10.17705/1CAIS.02604

Sledgianowski, D., Luftman, J., \& Reilly, R. (2006). Development and validation of an instrument to measure maturity of IT business strategic alignment mechanisms. Information Resources Management Journal, 19(3), 18-33, https://doi.org/10.4018/irmj.2006070102

Sousa, H. P., \& do Prado Leite, J. C. s. (2014). Modeling organizational alignment. In International Conference on Conceptual Modeling, pp. 407-414. Springer, Cham, https://doi.org/10.1007/978-3-319-12206-9 34

Stern, P.C. (1994). Eroding grounded theory. in Morse, J.M.(Ed.), Critical Issues in Qualitative Research Methods, Sage Publications, Thousand Oaks, CA, pp. 212-223.

Strauss, A., \& Corbin, J. M. (1998). Basics of Qualitative Research: Techniques and Procedures for Developing Grounded Theory (2nd Edition). Thousand Oaks: Sage Publ.

Strong, D. M., \& Volkoff, O. (2010). Understanding organization-enterprise system fit: a path to theorizing the information technology artifact. MIS Quarterly, 34(4), 731-756, https://doi.org/10.2307/25750703

Tallon, P., Queiroz, M., Coltman, T., \& Sharma, R. (2016). Business Process and Information Technology Alignment: Construct Conceptualization, Empirical Illustration, and Directions for Future Research. Journal of the Association for Information Systems, 17(9), 563589, https://doi.org/10.17705/1jais.00438

Tarafdar, M., \& Qrunfleh, S. (2009). IT-Business Alignment: A Two-Level Analysis. Information Systems Management, 26(4), 338-349, https://doi. org/10.1080/10580530903245705

Teo, T.S.H., \& King, W.R. (1997). Integration between Business Planning and Information Systems Planning: An Evolutionary-Contingency Perspective. Journal of Management Information Systems, 14(1), 185-214, https://doi.org/10.1080/07421222.1997.11518158

Trang, S., Mandrella, M., Marrone, M., \& Kolbe, L. (2021). Co-creating business value through IT-business operational alignment in inter-organisational relationships: empirical evidence from regional networks. European Journal of Information Systems, 1-22, https://doi.org/1 0.1080/0960085X.2020.1869914

Venkatraman, N. (1989). The Concept of Fit in Strategy Research: Toward Verbal and Statistical Correspondence. Academy of Management Review, 14(3), 423444, https://doi.org/10.2307/258177

Wagner, H.T., Beimborn, D., \& Weitzel, T. (2014). How Social Capital Among Information Technology and Business Units Drives Operational Alignment and IT Business Value. Journal of Management Information Systems, 31(1), 241-272, https://doi.org/10.2753/ MIS0742-1222310110

Walker, G.H., Stanton, N.A., Salmon, P.M. \& Jenkins, D.P. (2008). A review of socio-technical systems theory: a classic concept for new command and control paradigms. Theoretical Issues in Ergonomics Science, 9(6), 479-499, https://doi.org/10.1080/14639220701635470

Wan-Kadir, W. M., \& Loucopoulos, P. (2004). Relating evolving business rules to software design. Journal of Systems architecture, 50(7), 367-382, https://doi. org/10.1016/j.sysarc.2003.09.006

Weerakkody, V., Currie, W., \& Ekanayake, Y. (2003). Reengineering business processes through application service providers: Challenges, issues and complexities. Business Process Management Journal, 9(6), 776-794, https://doi.org/10.1108/14637150310506693

Wiesche, M., Jurisch, M.C., Yetton, P.W. \& Krcmar, H. (2017). Grounded theory methodology in information systems research. MIS Quarterly, 41(3), 685-701, http://doi.org/10.25300/MISQ/2017/41.3.02

Zhou, J., Bi, G., Liu, H., Fang, Y., \& Hua, Z. (2018). Understanding employee competence, operational IS alignment, and organizational agility - An ambidexterity perspective. Information \& Management, 55, 695708, https://doi.org/10.1016/j.im.2018.02.002

Olfat Ganji Bidmeshk is a Ph.D. candidate in Information Technology Management at the Department of Management, Ferdowsi University of Mashhad, Iran. Her research interests include Business-IT alignment, systems analysis and design, and Business Informatics. She is currently working as a visiting Ph.D. student at the Sauder School of Business, Management Information Systems Department, University of British Columbia, Vancouver, Canada. 
Mohammad Mehraeen is a Professor of Information Systems at the Department of Management, Ferdowsi University of Mashhad, Iran. He obtained his Ph.D. from the University of Manchester, UK. His current research interests include electronic government, digital transformation, business Informatics, Big data and IOT. He is currently working as a visiting professor at the DeGroote School of Business, Information Systems Department, McMaster University, Hamilton, Canada.

Alireza Pooya is a Professor of Industrial Management at the Department of Management, Ferdowsi University of Mashhad, Iran. He obtained his Ph.D. from the Tarbiat Modares University, Iran. His current research interests include systems thinking, dynamic systems, optimal control, operations management, production planning, manufacturing strategy, and business process management. Currently, he is a Manager of Human Resource and Organizational Change at the Ferdowsi University of Mashhad.

Yaghoob Maharati is an Associate Professor of Entrepreneurship Management at the Department of Management, Ferdowsi University of Mashhad, Iran. He obtained his Ph.D. from the University Putra Malaysia (UPM). His current research interests include entrepreneurship, research method, management theory, critical review of management theory, and business plan. Currently, he is a Manager of Planning and Budgeting at the Ferdowsi University of Mashhad. 


\section{Appendix A: Literature review on business-IS alignment}

We categorize approaches on business-IS alignment into two main categories: (1) approaches that aim to achieve strategic alignment and (2) approaches that aim to achieve operational alignment.

\section{A.1. Approaches focusing on strategic alignment}

Studies that aim to achieve strategic alignment can be categorized into studies that emphasize three main aspects: (1) social and structural, (2) technical, and (3) socio-technical (Table A.1).

Table 2: A.1. Selected studies on strategic alignment

\begin{tabular}{|c|c|c|}
\hline Aspect & Key concept & Reference \\
\hline \multirow{4}{*}{ Social } & $\begin{array}{l}\text { Flexibility of organizational structure (data processing procedures, delegation of } \\
\text { authority, and segregation of departments) to manage organizational changes }\end{array}$ & Lester \& Parnell (2002) \\
\hline & $\begin{array}{l}\text { Top management team's (TMT) trust in chief information officer (CIO), } \mathrm{ClO} \text { 's trust } \\
\text { in TMT, shared language, and shared understanding of the role of IT. }\end{array}$ & Preston \& Karahanna (2009) \\
\hline & $\begin{array}{l}\text { Management styles, culture of innovation and risk-taking among staff, beliefs and } \\
\text { shared values among staff, partnership, cooperation and trustworthiness among } \\
\text { them }\end{array}$ & Cram (2012) \\
\hline & $\begin{array}{l}\text { Communication, senior management support, the participation of research and } \\
\text { development managers in the development of strategies, and interdisciplinary } \\
\text { support by IS and business during the development of IS }\end{array}$ & Alsudiri et al. (2013) \\
\hline \multirow[t]{2}{*}{ Technical } & $\begin{array}{l}\text { Standards available in the field of IT to create a common language among the de- } \\
\text { partments and provide interdisciplinary information sharing. }\end{array}$ & $\begin{array}{l}\text { Henderson \& Venkatraman } \\
\text { (1993) }\end{array}$ \\
\hline & Integration of IT architecture and infrastructure & Sledgianowski et al. (2006) \\
\hline \multirow{5}{*}{ Socio-technical } & $\begin{array}{l}\text { Decision style of senior management, fluctuations of management tenure, the } \\
\text { way the applications are developed, the complexity of management tasks, and the } \\
\text { physical location of IS managers }\end{array}$ & Pyburn (1983) \\
\hline & $\begin{array}{l}\text { Transparency and perception of the mission, objectives and priorities of the or- } \\
\text { ganization, effective communication, IS managers' involvement in the process of } \\
\text { planning, and their realistic expectations of IS }\end{array}$ & Lederer \& Mendelow (1989) \\
\hline & Communication, governance, skill, sourcing, IT professionals, and project. & Tarafdar \& Qrunfleh (2009) \\
\hline & $\begin{array}{l}\text { Strategic alignment maturity based on six dimensions: communication, competen- } \\
\text { cy and value measurements, governance, participation, scope and architecture, } \\
\text { and skill. }\end{array}$ & Luftman (2003) \\
\hline & Intellectual and social alignment & Reich \& Benbasat (2000) \\
\hline
\end{tabular}

\section{A.2. Approaches focusing on operational alignment}

Existing literature focused on the operational level of alignment either have used modeling languages (MLs) to link models in BPs and software systems (SSs) or have focused on identifying the social antecedents and their effect on operational alignment (Table A.2). 
Table 3: A.2. Selected studies on modeling langauges

\begin{tabular}{|c|c|c|c|c|c|}
\hline Category & \multicolumn{4}{|c|}{ Focus } & Reference \\
\hline \multirow{13}{*}{$\begin{array}{l}\text { Modeling } \\
\text { Languages }\end{array}$} & \multirow{5}{*}{$\begin{array}{l}\text { Aligning BR (Business Requirements) and BP } \\
\text { (Business Processes) }\end{array}$} & BR & $\mathrm{BP}$ & SS & \\
\hline & & GRL & BPMN & - & Li et al. (2015) \\
\hline & & MAP & BPMN & - & $\begin{array}{l}\text { Kraiem et al. } \\
\qquad(2014)\end{array}$ \\
\hline & & $i^{*}$ & BPMN & - & $\begin{array}{l}\text { Sousa and Julio } \\
\text { (2014) }\end{array}$ \\
\hline & & Tropos & BPEL & - & $\begin{array}{l}\text { Frankova et al. } \\
\qquad(2011)\end{array}$ \\
\hline & \multirow{3}{*}{ Aligning BR and SS (Software Systems) } & BMM & - & SoaML & $\begin{array}{l}\text { Han et al. } \\
\text { (2009) }\end{array}$ \\
\hline & & Tropos & - & Tropos & $\begin{array}{l}\text { Gehlert et al. } \\
\qquad(2008)\end{array}$ \\
\hline & & UML & - & UML & $\begin{array}{c}\text { Wan-Kadir and } \\
\text { Loucopoulos } \\
\text { (2004) }\end{array}$ \\
\hline & \multirow{4}{*}{ Aligning $\mathrm{BP}$ and SS } & & UML & UML & $\begin{array}{l}\text { Aversano et al. } \\
\text { (2016) }\end{array}$ \\
\hline & & - & $\begin{array}{l}\text { BPMN \& e3 } \\
\text { value }\end{array}$ & UML & $\begin{array}{l}\text { DeCastro et al. } \\
\qquad(2011\end{array}$ \\
\hline & & - & BPMN & SoaML & $\begin{array}{l}\text { Elvesater et al. } \\
\qquad(2010)\end{array}$ \\
\hline & & - & BPMN & UML & Cibran (2009), \\
\hline & Aligning $\mathrm{BR}, \mathrm{BP}$ and $\mathrm{SS}$ & $i^{*}$ & UML & UML & $\begin{array}{l}\text { Doumi et al. } \\
\text { (2013) }\end{array}$ \\
\hline \multirow[b]{3}{*}{$\begin{array}{l}\text { Social } \\
\text { antecedents }\end{array}$} & \multicolumn{4}{|c|}{ Social capital (cognitive linkage, structural linkage, and relational linkage) } & $\begin{array}{l}\text { Wagner et al. } \\
\qquad(2014)\end{array}$ \\
\hline & \multicolumn{4}{|c|}{ Shared competence between business and IS departments } & $\begin{array}{l}\text { Zhou et al. } \\
\qquad(2018)\end{array}$ \\
\hline & \multicolumn{4}{|c|}{$\begin{array}{l}\text { Shared understanding between business and IS by overcoming seven user-related elici- } \\
\text { tations problems: (1) communication flaws between the project team and customer, (2) } \\
\text { terminological problems, (3) weak knowledge of application domain, (4) stakeholders } \\
\text { with difficulties in separating requirements from previously known solution design, (5) in- } \\
\text { complete and hidden requirements, (6) missing traceability, and (7) inconsistent require- } \\
\text { ments. }\end{array}$} & $\begin{array}{l}\text { Bagheri et al. } \\
\qquad(2019)\end{array}$ \\
\hline
\end{tabular}




\section{Appendix B: Types of BP functions}

\section{Table 4: B.1. Types of BP functions}

\begin{tabular}{|c|c|c|c|}
\hline BP function & Element of BP function & \multicolumn{2}{|c|}{ Type of BP Function } \\
\hline Strategic management & $\begin{array}{l}\text { - Strategy compilation } \\
\text { - Strategy implementation } \\
\text { - Strategy assessment }\end{array}$ & \multirow{2}{*}{$\begin{array}{l}\text { Management } \\
\text { functions }\end{array}$} & \multirow{7}{*}{$\begin{array}{l}\text { Primary } \\
\text { functions }\end{array}$} \\
\hline Quality management & $\begin{array}{l}\text { - Process management } \\
\text { - Project management } \\
\text { - Performance measurement }\end{array}$ & & \\
\hline Learning management & $\begin{array}{l}\text { - Learning planning } \\
\text { - Planning for admissions } \\
\text { - Planning administrative and teaching services } \\
\text { - Learning assessment } \\
\text { - Admitting a study }\end{array}$ & \multirow{2}{*}{$\begin{array}{l}\text { Core business } \\
\text { functions }\end{array}$} & \\
\hline Research management & $\begin{array}{l}\text { - Research policy } \\
\text { - Research services } \\
\text { - Research achievements } \\
\text { - Technology transfer }\end{array}$ & & \\
\hline Student services management & $\begin{array}{l}\text { - Plan student services } \\
\text { - Provide student services } \\
\text { - Monitor and evaluate student services } \\
\text { - } \text { Terminate student services }\end{array}$ & \multirow{3}{*}{$\begin{array}{l}\text { Non-core busi- } \\
\text { ness functions }\end{array}$} & \\
\hline $\begin{array}{l}\text { Social and cultural manage- } \\
\text { ment }\end{array}$ & $\begin{array}{l}\text { - Provide cultural and social planning } \\
\text { - Provide cultural and social services \& products } \\
\text { - Provide cultural and social facilities } \\
\text { - Monitor cultural and social services }\end{array}$ & & \\
\hline Communication management & $\begin{array}{l}\text { - Public relations } \\
\text { - Interactions with community } \\
\text { - International university interactions } \\
\text { - Provide out-of-school services }\end{array}$ & & \\
\hline Assets management & $\begin{array}{l}\text { - Physical resources management } \\
\text { - Goods and services management }\end{array}$ & \multirow{4}{*}{\multicolumn{2}{|c|}{ Support functions }} \\
\hline $\begin{array}{c}\text { Financial resource manage- } \\
\text { ment }\end{array}$ & $\begin{array}{l}\text { - Resource and financial expenses planning } \\
\text { - Collection and distribution of financial credits } \\
\text { - Payment of expenses } \\
\text { - Financial monitoring }\end{array}$ & & \\
\hline HRM & $\begin{array}{l}\text { - Providing human resources planning } \\
\text { - Hiring, supplying and selecting human resourc- } \\
\text { - } \text { - Developing HR's skills } \\
\text { - Providing facilities and benefits for human re- } \\
\text { - } \text { sources } \\
\text { - } \text { Providing safety and health of human resources } \\
\end{array}$ & & \\
\hline ICT management & $\begin{array}{l}\text { - ICT planning } \\
\text { - Communication and networks management } \\
\text { - Information and data management } \\
\text { - Information and communication security man- } \\
\text { - } \text { - Software and systems management } \\
\text { - Software and hardware support }\end{array}$ & & \\
\hline
\end{tabular}




\section{Appendix C: Types of IS capabilities}

Table 5: C.1. Types of IS capabilities based on Socio-Technical System (STS) theory

\begin{tabular}{|c|c|c|c|c|}
\hline IS capability & \multirow{3}{*}{$\begin{array}{l}\text { Element of IS capability } \\
\text { - } \quad \text { Top business management } \\
\text { IS management } \\
\text { - } \quad \text { Commitment to the strategic use of IS should be considered by the } \\
\text { - } \quad \text { top business management. } \\
\text { realistic. } \\
\text { - The top business management awareness of the contribution of IS to } \\
\text { business goals should be raised. } \\
\text { The top business management awareness of the quality and quantity } \\
\text { - } \quad \text { IS-based service should be raised. } \\
\text { - } \quad \text { The horiness missions and objectives should be reflected in the IS plan. } \\
\text { - } \quad \text { Allocating IS resources should be delegated to IS management. } \\
\text { - The culture of the organization should be built on innovation and } \\
\text { change-readiness. }\end{array}$} & \multicolumn{3}{|c|}{ Type of IS capability } \\
\hline \multirow[b]{2}{*}{$\begin{array}{l}\text { Strategic level } \\
\text { of ISs }\end{array}$} & & \multicolumn{2}{|c|}{ Actor } & \multirow{4}{*}{$\begin{array}{l}\text { Social } \\
\text { subsystem }\end{array}$} \\
\hline & & $\begin{array}{l}\text { Authority } \\
\text { system }\end{array}$ & \multirow[t]{3}{*}{ Structure } & \\
\hline \multirow[t]{4}{*}{$\begin{array}{l}\text { - Strategic capa- } \\
\text { bilities }\end{array}$} & $\begin{array}{l}\text { Setting up proper standards for ISs to enable the following: } \\
\text { - } \quad \text { Adaptation of diversified internal and external IS resources (network, } \\
\text { hardware, software, data, and people), which are adjusted according } \\
\text { to the business goals } \\
\text { - } \quad \text { Flexibility of ISs } \\
\text { - Integration of ISs }\end{array}$ & $\begin{array}{l}\text { Workflow } \\
\text { system }\end{array}$ & & \\
\hline & $\begin{array}{l}\text { - Creating common norms and patterns of behavior among IS strategic } \\
\text { committee members }\end{array}$ & $\begin{array}{l}\text { Commu- } \\
\text { nication } \\
\text { system }\end{array}$ & & \\
\hline & $\begin{array}{l}\text { - Analyzing the environmental opportunities and threats and the busi- } \\
\text { ness strengths and weaknesses } \\
\text { - Creating sustainable competitive advantage }\end{array}$ & \multicolumn{2}{|c|}{ Task } & Technical \\
\hline & $\begin{array}{ll}\text { - } & \text { Expert System (ES) } \\
\text { - } & \text { Executive Support System (ESS) }\end{array}$ & \multicolumn{2}{|c|}{ Technology } & \\
\hline \multirow{6}{*}{$\begin{array}{l}\text { Management level } \\
\text { of ISs } \\
\text { - Management } \\
\text { capabilities }\end{array}$} & $\begin{array}{l}\text { - } \quad \text { BP management } \\
\text { - IS management }\end{array}$ & \multicolumn{2}{|c|}{ Actor } & \multirow{4}{*}{$\begin{array}{l}\text { Social } \\
\text { subsystem }\end{array}$} \\
\hline & $\begin{array}{l}\text { - Knowledge of IS-based services should be acquired by BP manage- } \\
\text { ment. } \\
\text { - Support of IS activities should be considered by BP management. } \\
\text { - } \quad \text { agement. } \\
\text { Participatory management should be adopted by BP and IS manage- } \\
\text { ment. } \\
\text { Perspective of BP and IS management should be compatible with BP } \\
\text { requirements. }\end{array}$ & $\begin{array}{l}\text { Authority } \\
\text { system }\end{array}$ & \multirow[t]{3}{*}{ Structure } & \\
\hline & $\begin{array}{l}\text { - Setting up proper standards for IS projects investment based on the } \\
\text { business projects }\end{array}$ & $\begin{array}{l}\text { Workflow } \\
\text { system }\end{array}$ & & \\
\hline & - Defining common language between BP and IS managements & $\begin{array}{l}\text { Commu- } \\
\text { nication } \\
\text { system }\end{array}$ & & \\
\hline & $\begin{array}{l}\text { - } \quad \text { Planning IS projects/resources based on BP requirements } \\
\text { - } \quad \text { Organizing IS projects/resources based on BP requirements } \\
\text { - } \quad \text { Decision making in IS projects/resources based on BP requirements } \\
\text { - Measuring the performance of IS projects/resources based on BP re- } \\
\text { quirements }\end{array}$ & \multicolumn{2}{|c|}{ Task } & \multirow[t]{2}{*}{$\begin{array}{l}\text { Technical } \\
\text { subsystem }\end{array}$} \\
\hline & $\begin{array}{l}\text { - } \quad \text { Decision Support System (DSS) } \\
\text { Management Information System (MIS) }\end{array}$ & \multicolumn{2}{|c|}{ Technology } & \\
\hline
\end{tabular}


Table 5: C.1. Types of IS capabilities based on Socio-Technical System (STS) theory (coninues)

\begin{tabular}{|c|c|c|c|c|}
\hline IS capability & Element of IS capability & \multicolumn{3}{|c|}{ Type of IS capability } \\
\hline \multirow{6}{*}{$\begin{array}{l}\text { Knowledge level } \\
\text { of ISs } \\
\text { - } \quad \text { Knowl- } \\
\text { edge-based } \\
\text { capabilities }\end{array}$} & \multirow{2}{*}{$\begin{array}{l}\text { - } \quad \text { Knowledge workers } \\
\text { - } \quad \text { Close bilateral cooperation should be in place for knowledge workers } \\
\text { in BP and IS departments. } \\
\text { - Mutual trust and common values should be perceived between } \\
\text { knowledge workers in BP and IS departments. } \\
\text { - Participatory programs should be frequently and formally held be- } \\
\text { tween knowledge workers in BP and IS departments. } \\
\text { - Job rotation should be available between BP and IS departments. }\end{array}$} & \multicolumn{2}{|c|}{ Actor } & \multirow{4}{*}{$\begin{array}{c}\text { Social } \\
\text { subsystem }\end{array}$} \\
\hline & & $\begin{array}{l}\text { Authority } \\
\text { system }\end{array}$ & \multirow{3}{*}{ Structure } & \\
\hline & $\begin{array}{l}\text { Setting up proper standards for } \\
\text { - } \quad \text { Interdepartmental interactions between BP and IS departments } \\
\text { - Interdepartmental reporting between BP and IS departments }\end{array}$ & $\begin{array}{l}\text { Workflow } \\
\text { system }\end{array}$ & & \\
\hline & $\begin{array}{l}\text { - Establishing an informal communications network between IS and BP } \\
\text { departments. }\end{array}$ & $\begin{array}{l}\text { Commu- } \\
\text { nication } \\
\text { system }\end{array}$ & & \\
\hline & $\begin{array}{l}\text { - } \quad \text { Knowledge creation and gathering } \\
\text { - } \quad \text { Knowledge assessment } \\
\text { - } \quad \text { Knowledge sharing and dissemination } \\
\text { - } \quad \text { Knowledge application }\end{array}$ & \multicolumn{2}{|c|}{ Task } & $\begin{array}{l}\text { Technical } \\
\text { subsystem }\end{array}$ \\
\hline & $\begin{array}{ll}\text { - } & \text { Knowledge Work System (KWS) } \\
\text { - } & \text { Group Collaboration System (GCS)s } \\
\text { Office System (OS) }\end{array}$ & \multicolumn{2}{|c|}{ Technology } & \\
\hline \multirow{4}{*}{$\begin{array}{l}\text { Operational level } \\
\text { of IS } \\
\text { - } \begin{array}{l}\text { Operational } \\
\text { capabilities }\end{array}\end{array}$} & - Organizational workers & \multicolumn{2}{|c|}{ Actor } & \multirow[b]{2}{*}{$\begin{array}{c}\text { Social } \\
\text { subsystem }\end{array}$} \\
\hline & $\begin{array}{l}\text { Information in the IS infrastructure should be: } \\
\text { - } \quad \text { Transparent } \\
\text { - } \quad \text { Accessible } \\
\text { - } \quad \text { Accurate } \\
\text { - } \quad \text { Up-tiable-date }\end{array}$ & $\begin{array}{l}\text { Authority } \\
\text { system }\end{array}$ & Structure & \\
\hline & $\begin{array}{l}\text { - } \quad \text { Recording of daily activities and transactions } \\
\text { - Using historical data on activities in organization } \\
\text { Monitoring the performance of internal processes and relations with } \\
\text { the external environment }\end{array}$ & \multicolumn{2}{|c|}{ Task } & $\begin{array}{l}\text { Technical } \\
\text { subsystem }\end{array}$ \\
\hline & $\begin{array}{l}\text { - Office Automation System (OAS) } \\
\text { - } \quad \text { Transaction Processing System (TPS) }\end{array}$ & \multicolumn{2}{|c|}{ Technology } & \\
\hline
\end{tabular}

